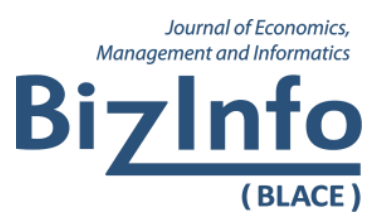

Year 2019, Volume 10, Number 2, pp. 125-138

\author{
Прегледни рад/ Review paper \\ УДК/UDC: 330.341.1(497.11) \\ 338.45:[004:007
}

doi:10.5937/bizinfo1902125S

\title{
THE DEVELOPMENT POTENTIAL OF THE HIGH-TECH INDUSTRY IN SERBIA
}

\section{РАЗВОЈНИ ПОТЕНЦИЈАЛ ВИСОКО ТЕХНОЛОШКЕ ИНДУСТРИЈЕ У СРБИЈИ}

\author{
Nikola Savanović \\ Singidunum University, Belgrade, Serbia \\ Miro Sokić \\ Dunav Insurance Company, Belgrade, Serbia \\ Slađana Subotić ${ }^{1}$ \\ University of Kragujevac, Faculty of Economics, Kragujevac, Serbia
}

\begin{abstract}
The development and deployment of high technology is a key driver of economic growth, a source of competitiveness, high value-added creation and the creation of well-paying jobs, both in developed countries and in countries in different stages of development. With this in mind, the paper follows the implementation of the sectoral approach followed by the High-technology industry to measure economic performance and the current contribution of the High-technology industry to economic development in Serbia. First, the economic importance of the high-tech industry in the European Union is explored, and then the development of the high-tech industry in Serbia from a development perspective in the future. The concluding part of the paper outlines the measures of active economic policy that must be implemented in order to accelerate the development of the domestic High-technology industry and to make it really the basis for the economic and overall social development of Serbia in the coming decades.
\end{abstract}

Keywords: high-tech industry, economic growth, economic policy

${ }^{1}$ sladjanas@kg.ac.rs 
Сажкетак: Развој и примене високе технологије је кључни покретач економског раста, извор конкурентности, стварања високе додате вредности и креирања добро плаћених послова како у развијеним земьама тако и у земьама које се налазе у различитим фазама развоја. Имајући то y виду, у раду се применом секторског приступа високотехнолошке индустрије прате мере економске перформансе и тренутни допринос високотехнолошке индустрије привредном развоју Србије. Прво се истражује економски значај високотехнолошке индустрије у Европској унији, а затии развијеност високотехнолошке индустрије у Србији са перспектива развоја у будућности. У закључном делу рада се указује на мере активне економске политике које је нужно спровести како би се динамизирао развој домаће високотехнолошке индустрије и како би она стварно постала основа економског и укупног друштвеног развоја Србије у наредним деценијама.

Кључне речи: високотехнолошка индустрија, привредни раст, економска политика

\section{INTRODUCTION}

Increasing economic globalization processes emphasize the importance of developing and implementing high technology as a key driver of economic growth and a source of competitiveness, creating high- added value and creating well-paying jobs (Filipović at al., 2016). The development and practical application of new high technologies is essential in the global competitiveness race (Cvetanović and Novaković, 2019), not only of individual companies, but also of countries and wider socio-economic regions around the world. The most developed countries today are precisely those in which the high-tech sectors play a significant role and are the basis of new growth, employment and competitiveness (Filipović at al., 2015, p. 200). The importance of the High-technology industry outweighs their simple participation in an economy as it significantly improves the performance and development capabilities of other industries.

In the European Union, high-tech sectors are key drivers of economic growth, productivity and well-being, and generally a source of high value-added and well-paid jobs (European Commission, 2009, p. 151). Accordingly, the EU has established a strategic framework for scientific and technological development in the Lisbon Strategy, which has been redefined in the Europe 2020 Strategy. The Europe 2020 Strategy contains a vision of a European social market economy for the $21^{\text {st }}$ century based on three interconnected priorities: (1) smart growth implying the development of a knowledge and innovation based economy; (2) sustainable growth, which involves promoting a more economical, greener and more competitive economy; and (3) inclusive growth, which includes stimulating a high-employment economy, providing 
social and geographical cohesion, and incorporating trade-opening initiatives for 'sectors of the future', including high-tech products and services (Eurostat, 2019a).

Although Serbia is far behind in economic and technological development relative to EU countries, and is comparable to neighboring countries (Montenegro, Albania, Northern Macedonia, and Bosnia and Herzegovina) that are at the very core of Europe (Nikolić at al, 2017; Cvetanović at al, 2015; Nedić at al, 2014), the development of the High-technology industry is essential for the dynamics and sustainability of Serbia's economic development in the coming decades of the $21^{\text {st }}$ century. Accordingly, this paper measures the economic performance and current contribution of the High-technology industry to economic development in Serbia.

The paper applies the sectoral approach followed by the High-technology industry, which implies a particular aggregation of manufacturing industries according to the level of their technological intensity (R\&D expenditure / value added), using the Statistical Classification of Economic Activities in the European Community (NACE Rev.2) at the 2 digit level for compiling groups (Eurostat, 2019b), so the high-tech industry means: Manufacture of basic pharmaceutical products and pharmaceutical preparations and Manufacture of computer, electronic and optical products.

\section{ECONOMIC SIGNIFICANCE OF THE HIGH-TECH INDUSTRY IN THE EUROPEAN UNION}

More than 46.000 high-tech companies operated in the European Union in 2014 (the latest available data). The largest number of these enterprises (around 53\% of the high-tech enterprises in the EU-28) operated in Germany (8.827 enterprises), the United Kingdom (6.504), Italy (5.453) and Poland (3.461).

Graph 1. Basic performance indicators for the high-tech industry in the EU 28 in 2014.

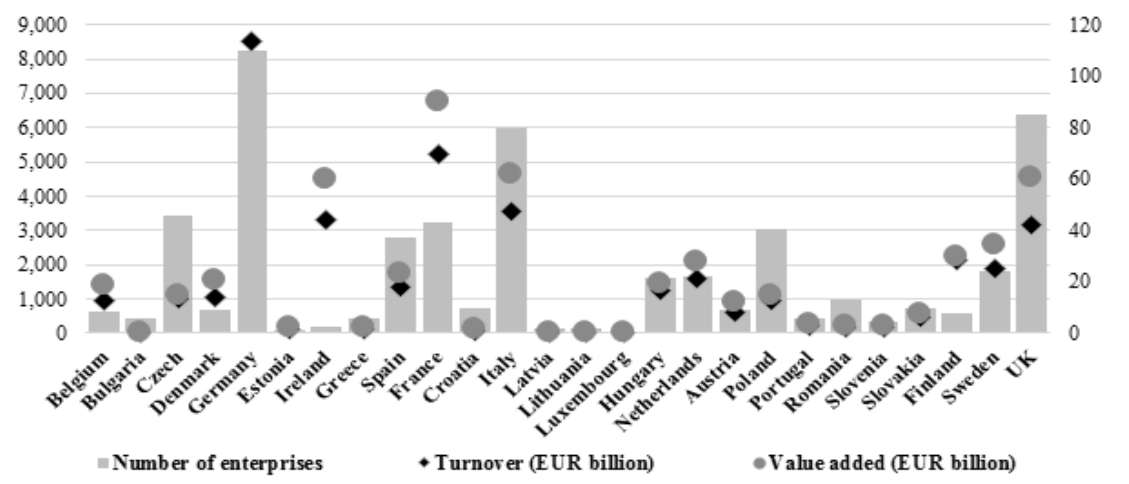

Source: autors, based on the Eurostat data, (Eurostat, 2019c) 
The highest turnover in 2014 was generated by high-tech companies from Germany (121 billion, more than twice that of countries with comparable numbers of high-tech enterprises), followed by high-tech companies from France ( $€ 68$ billion) and Italy ( $€ 44$ billion). The distribution of value- added is very similar in the view that high-tech companies from Germany are dominated ( $€ 43$ billion), followed by high-tech companies from France and the United Kingdom (with $€ 20$ and $€ 17$ billion respectively).

High-tech products accounted for $17.0 \%$ of the value of all EU-28 exports in 2014 , although with high inequalities between countries, ranging from $35.3 \%$ in Malta to only 2.9\% in Greece. The leading European exporter of high-tech products to the rest of the world is Germany, followed by the Netherlands, France and the United Kingdom. At EU level, imports of high-tech products exceeded exports (a deficit of $€ 22$ billion), and only Belgium, Denmark, Germany, Ireland, France, the Netherlands and Austria recorded a surplus in foreign trade in high-tech products.

\section{DEVELOPMENT OF HIGH-TECHNOLOGY INDUSTRY IN SERBIA}

The development of the High-technology industry in Serbia has a relatively long and in some periods, such as the 70 's and 80 's of the $20^{\text {th }}$ century, successful history. Although in terms of technological advancement, the domestic economy has always lagged far behind the most developed western economies, nevertheless in the 70s, and especially in the 80s, this gap was significantly reduced and in some segments almost completely disappeared. This success has been achieved through the advancement of the education system that has produced high quality and highly qualified personnel and significant investment in science and technological development, as well as the closed economy for many foreign products in this field.

During this period, very successful business systems were created, such as Galenika, Hemofarm, Srbolek and other pharmaceutical companies, as well as Electronic Industry from Nis as the leading domestic company in the field of Manufacture of computer, electronic and optical products. However, the economic and social crisis of the 1990s, manifested through the development of the once single market of the SFRY, followed by hyperinflation, sanctions, declining purchasing power and general macroeconomic and legal uncertainty, had a very negative impact on the functioning and development of all parts of the High-technology industry. Leading domestic companies have significantly reduced their business volume with a technical and technological lagging behind, which was particularly negative after the liberalization of foreign trade relations in the early $21^{\text {st }}$ century. A particular problem was the ownership transformation (through privatization) of companies from this region, where there are only a small number of 
successful examples (e.g. privatization of Hemofarm from Vrsac). All the above negative factors have led to a significant degradation of the business and development perspective of domestic companies of the High-technology industry and the decline in both domestic production and exports in this field.

As a result, only 1.360 companies operate in the High-technology industry in 2017 (accounting for $2.4 \%$ of Manufacturing, or $0.4 \%$ of the non-financial part of the economy). These companies employ 11.776 workers $(2.9 \%$ and $0.9 \%$ respectively), generating 107.1 billion dinars of turnover $(3.4 \%$ and $1.0 \%$ respectively) generate 28.1 billion dinars of GVA $(4.0 \%$ and $1.2 \%$ respectively), recorded 40.7 billion export dinars $(3.0 \%$ and $2.2 \%$ respectively) and generate a foreign trade deficit of 5.3 billion dinars.

Graph 2. Participation of High-technology industry shown by the basic indicators of business of Manufacturing industry and non-financial part of Serbian economy in 2017

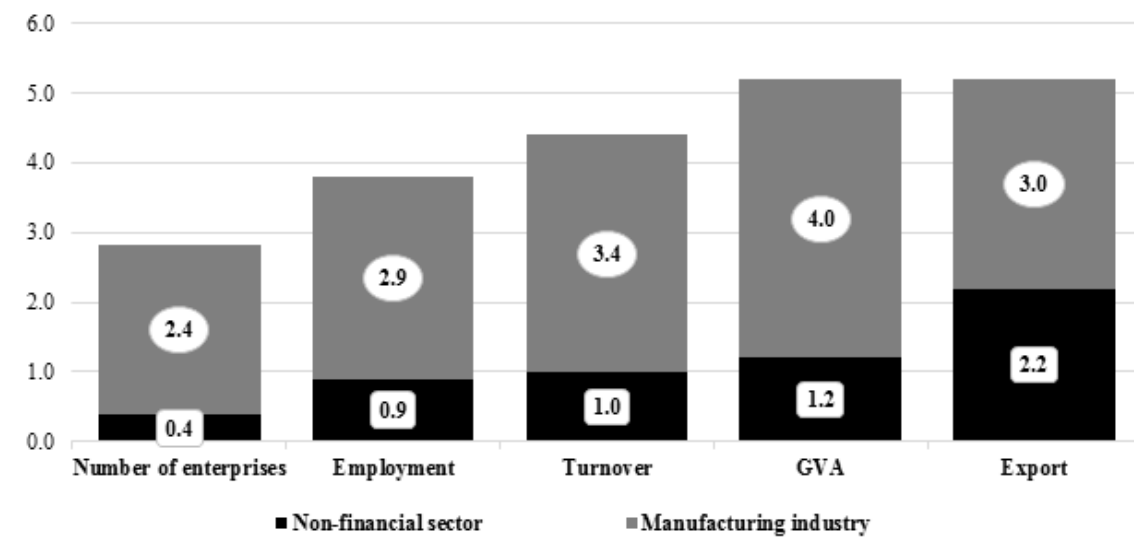

Source: autors, based on the Republic Statistical Office data

\subsection{NUMBER OF COMPANIES IN THE HIGH-TECHNOLOGY INDUSTRY IN SERBIA}

In 2017, 1.360 companies operated within the High-technology industry. 62 enterprises (4.6\% of all High-technology industry companies) are engaged in Manufacture of basic pharmaceutical products and pharmaceutical preparations, and 1.298 companies (95.4\%) in Manufacture of computer, electronic and optical products.

Table 1. Number of companies in the High-technology industry from 2010 to 2017

\begin{tabular}{|c|c|c|c|c|}
\hline Year & $\begin{array}{c}\text { Manufacture of basic } \\
\text { pharmaceutical products and } \\
\text { pharmaceutical preparations }\end{array}$ & $\begin{array}{c}\text { Manufacture of } \\
\text { computer, electronic } \\
\text { and optical products }\end{array}$ & $\begin{array}{c}\text { High- } \\
\text { technology } \\
\text { industry }\end{array}$ & $\begin{array}{c}\text { Annual } \\
\text { growth } \text { in } \\
\text { \% }\end{array}$ \\
\hline 2010 & 56 & 1,804 & $\mathbf{1 , 8 6 0}$ & 6.8 \\
\hline 2011 & 71 & 1,717 & $\mathbf{1 , 7 8 8}$ & -3.9 \\
\hline
\end{tabular}

BizInfo (Blace), 2019, Volume 10, Number 2, pp. 125-138 
Nikola Savanović, Miro Sokić, Slađana Subotić

\begin{tabular}{|l|l|l|l|l|}
\hline 2012 & 75 & 1,441 & $\mathbf{1 , 5 1 6}$ & -15.2 \\
\hline 2013 & 76 & 1,374 & $\mathbf{1 , 4 5 0}$ & -4.3 \\
\hline 2014 & 80 & 1,331 & $\mathbf{1 , 4 1 1}$ & -2.7 \\
\hline 2015 & 79 & 1,308 & $\mathbf{1 , 3 8 7}$ & -1.7 \\
\hline 2016 & 62 & 1,316 & $\mathbf{1 , 3 7 8}$ & -0.7 \\
\hline 2017 & 62 & 1,298 & -1.3 \\
\hline \multicolumn{2}{|r|}{ Compound Annual Growth Rate (CAGR) 2010-2017 } \\
\hline
\end{tabular}

Source: autors, based on the Republic Statistical Office data

In the period 2010-2017, the largest number of enterprises within the Hightechnology industry was operating in 2010 (1.860 companies), which would constantly decrease during the observed period to only 1.360 companies in 2017. In the period 2010-2017, the number of companies operating in the High-technology industry decreased by 500 enterprises, i.e. by an average of $3.5 \%$ annually.

Graph 3. Trends in the number of companies in the High-technology industry in 2010-2017

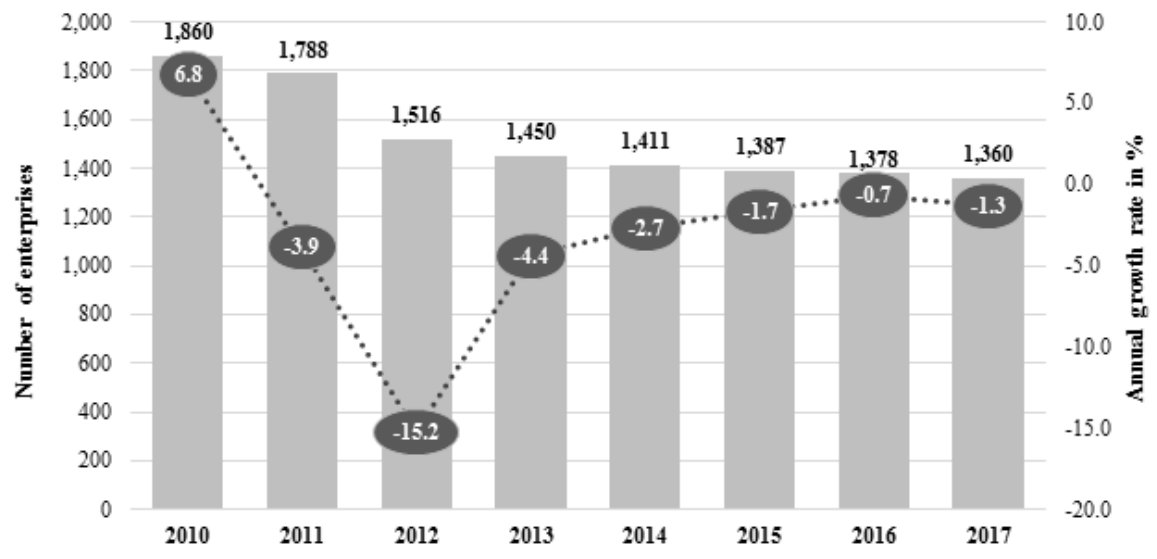

Source: autors, based on the Republic Statistical Office data

\subsection{EMPLOYMENT IN THE HIGH-TECHNOLOGY INDUSTRY IN SERBIA}

In 2017, the High-technology industry employed 11.776 employees, with 4.927 employees (42.1\% of all employees in the High-technology industry) working in Manufacture of basic pharmaceutical products and pharmaceutical preparations, and in Manufacture of computer, electronic and optical products 6.849 employees $(57.9 \%)$ were hired.

Table 2. Employment in the High-tech industry in 2010-2016 


\begin{tabular}{|c|c|c|c|c|}
\hline Year & $\begin{array}{c}\text { Manufacture of basic } \\
\text { pharmaceutical products and } \\
\text { pharmaceutical preparations }\end{array}$ & $\begin{array}{c}\text { Manufacture of } \\
\text { computer, electronic } \\
\text { and optical products }\end{array}$ & $\begin{array}{c}\text { High- } \\
\text { technology } \\
\text { industry }\end{array}$ & $\begin{array}{c}\text { Annual } \\
\text { growth } \text { in } \\
\text { \% }\end{array}$ \\
\hline 2010 & 6,723 & 9,703 & $\mathbf{1 6 , 4 2 6}$ & -6.7 \\
\hline 2011 & 6,502 & 8,730 & $\mathbf{1 5 , 2 3 2}$ & -7.3 \\
\hline 2012 & 6,207 & 7,709 & $\mathbf{1 3 , 9 1 6}$ & -8.6 \\
\hline 2013 & 5,354 & 7,475 & $\mathbf{1 2 , 8 2 9}$ & -7.8 \\
\hline 2014 & 4,954 & 7,097 & $\mathbf{1 2 , 0 5 1}$ & -6.1 \\
\hline 2015 & 5,021 & 7,515 & $\mathbf{1 2 , 5 3 6}$ & 4.0 \\
\hline 2016 & 5,158 & 7,085 & $\mathbf{1 2 , 2 4 3}$ & -2.3 \\
\hline 2017 & 4,927 & 6,849 & $\mathbf{1 1 , 7 7 6}$ & -3.8 \\
\hline \multicolumn{4}{|c|}{ Compound Annual Growth Rate (CAGR) 2010-2017 } \\
\hline
\end{tabular}

Source: autors, based on the Republic Statistical Office data

Highest employment in 2010-2017 in the High-technology industry was recorded in 2010 (16.426 workers), which is 4.650 workers more than in 2017, whereby employment in the High-technology industry decreased in the observed period by an average of $5.6 \%$ per year. The most pronounced decrease in employment in the observed period was recorded in 2012 (annual decrease of $-8.6 \%$ ), while a significant decrease was observed in 2011 ($7.3 \%$ ) and 2013 (decrease of $7.8 \%$ in relation to the previous year). Hightechnology industry employment growth was only recorded in 2015 (4.0\% annual growth).

Graph 4. Employment trends in the High-tech industry in 2010-2017

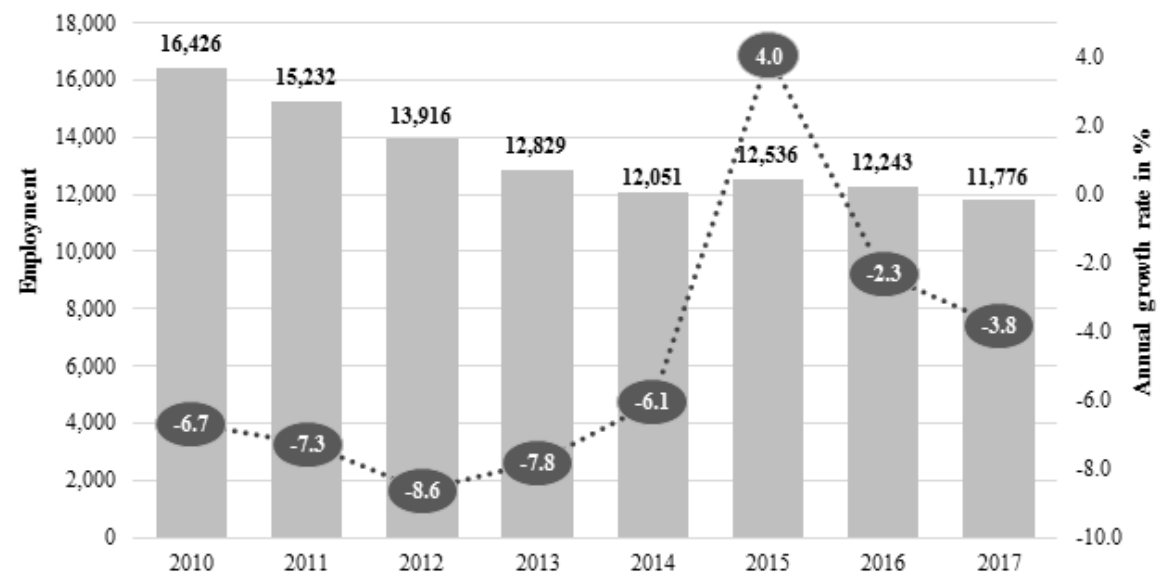

Source: autors, based on the Republic Statistical Office data

\subsection{GROSS VALUE ADDED OF HIGH-TECHNOLOGY INDUSTRIES OF SERBIA}


In 2017, the High-technology industry created GVA worth 28.1 billion dinars. The largest part of GVA within the High-technology industry was created in Manufacture of basic pharmaceutical products and pharmaceutical preparations (14.8 billion dinars - 52.6\% of GVA High-technology industry), and in Manufacture of computer, electronic and optical products GVA worth 13.3 billion dinars $(47.4 \%)$.

Table 3. Gross value added of High-technology industry in 2010-2017

\begin{tabular}{|c|c|c|c|c|}
\hline Year & $\begin{array}{c}\text { Manufacture of basic } \\
\text { pharmaceutical products and } \\
\text { pharmaceutical preparations } \\
\text { (billion RSD) }\end{array}$ & $\begin{array}{c}\text { Manufacture of } \\
\text { computer, electronic } \\
\text { and optical products } \\
\text { (billion RSD) }\end{array}$ & $\begin{array}{c}\text { High- } \\
\text { technology } \\
\text { industry } \\
\text { (billion } \\
\text { RSD) }\end{array}$ & $\begin{array}{c}\text { Annual } \\
\text { growth } \text { in } \\
\text { \% }\end{array}$ \\
\hline 2010 & 21.7 & 17.6 & $\mathbf{3 9 . 3}$ & -11.8 \\
\hline 2011 & 18.0 & 15.9 & $\mathbf{3 3 . 8}$ & -13.8 \\
\hline 2012 & 16.5 & 14.6 & $\mathbf{3 1 . 1}$ & -8.2 \\
\hline 2013 & 15.8 & 12.8 & $\mathbf{2 8 . 6}$ & -8.0 \\
\hline 2014 & 17.6 & 13.2 & $\mathbf{3 0 . 8}$ & 7.8 \\
\hline 2015 & 17.4 & 14.3 & $\mathbf{3 1 . 6}$ & 2.7 \\
\hline 2016 & 15.6 & 14.3 & $\mathbf{2 9 . 9}$ & -5.5 \\
\hline 2017 & 14.8 & 13.3 & $\mathbf{2 8 . 1}$ & -5.9 \\
\hline \multicolumn{2}{|c|}{ Compound Annual Growth Rate (CAGR) 2010-2017 } \\
\hline
\end{tabular}

Source: autors, based on the Republic Statistical Office data

The largest GVA in the High-technology industry was created in $2010(39.3$ billion dinars) and it is higher for 11.1 billion dinars than GVA created in 2017. GVA in the High-tech industry recorded negative growth rates over the period 2010-2017 except for 2014 and 2015 when positive annual growth rates of $7.8 \%$ and $2.7 \%$ respectively were recorded.

Graph 5. GVA trends in the High-tech industry in 2010-2017

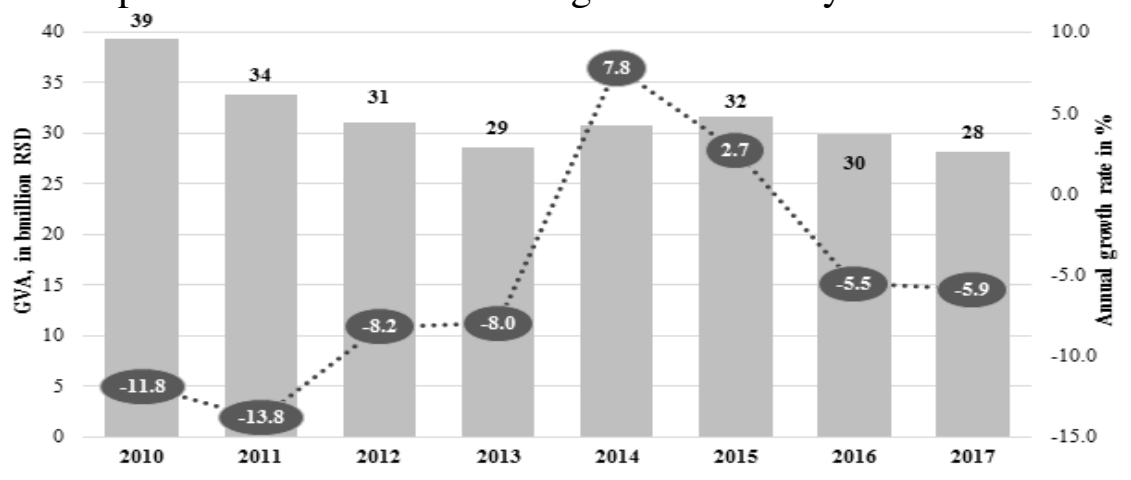

Source: autors, based on the Republic Statistical Office data

\subsection{EXPORTS OF HIGH-TECHNOLOGY INDUSTRY IN SERBIA}


Export value of High-technology industry of Serbia in 2017 amounted to 40.7 billion dinars which is 5.3 billion dinars less than imports (46 billion dinars), thus, negatively contributing to the balance of trade with foreign countries.

Graph 6. Net exports (surplus / deficit) of the High-tech industry in 20102017

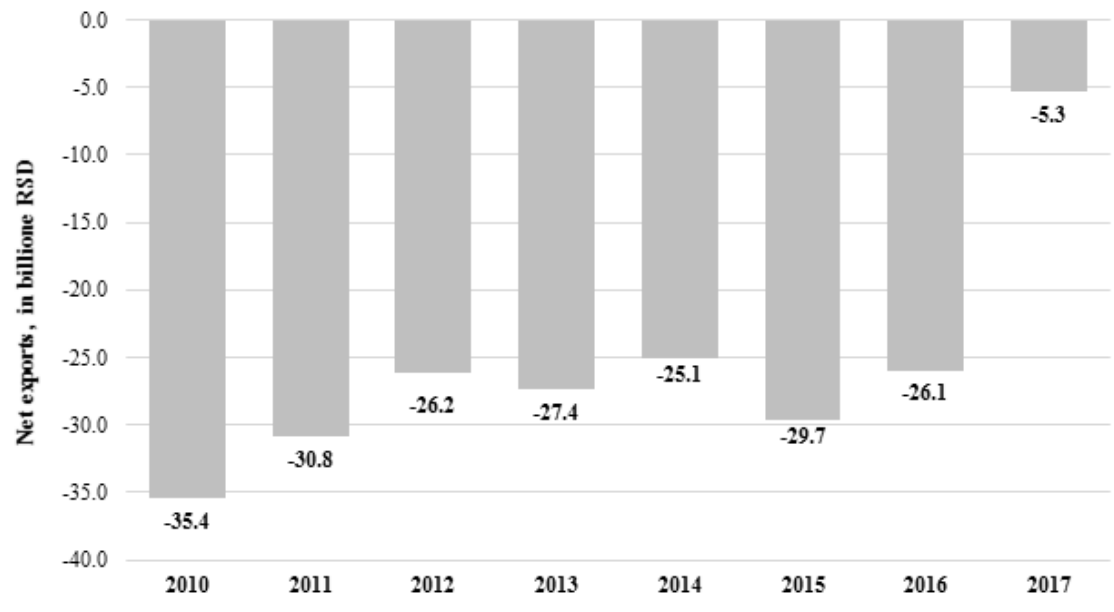

Source: autors, based on the Republic Statistical Office data

Domestic companies in 2017 exported Manufactures of basic pharmaceutical products and pharmaceutical preparations worth 27.6 billion dinars $(67.9 \%$ of High-technology industry exports) and they recorded a surplus in foreign trade of 22.6 billion dinars. Poor results were achieved by domestic companies exporting Manufacture of computer, electronic and optical products, as they recorded exports worth 13.1 billion dinars (32.1\%), recording a deficit of 10.3 billion dinars in trade with the world.

Table 4. High-technology industry exports in 2010-2017

\begin{tabular}{|c|c|c|c|c|}
\hline Year & $\begin{array}{c}\text { Manufacture of basic } \\
\text { pharmaceutical products and } \\
\text { pharmaceutical preparations } \\
\text { (billion RSD) }\end{array}$ & $\begin{array}{c}\text { Manufacture of } \\
\text { computer, electronic } \\
\text { and optical products } \\
\text { (billion RSD) }\end{array}$ & $\begin{array}{c}\text { High- } \\
\text { technology } \\
\text { industry } \\
\text { (billion } \\
\text { RSD) }\end{array}$ & $\begin{array}{c}\text { Annual } \\
\text { growth in } \\
\text { \% }\end{array}$ \\
\hline 2010 & 21.9 & 11.3 & $\mathbf{3 3 . 2}$ & 22.9 \\
\hline 2011 & 16.4 & 9.5 & $\mathbf{2 5 . 9}$ & -21.9 \\
\hline 2012 & 25.5 & 10.2 & $\mathbf{3 5 . 7}$ & 37.6 \\
\hline 2013 & 22.2 & 8.2 & $\mathbf{3 0 . 4}$ & -14.9 \\
\hline 2014 & 22.5 & 10.3 & $\mathbf{3 2 . 8}$ & 8.0 \\
\hline 2015 & 24.1 & 15.9 & $\mathbf{4 0 . 0}$ & 21.8 \\
\hline 2016 & 24.7 & 15.4 & $\mathbf{4 0 . 1}$ & 0.3 \\
\hline 2017 & 27.6 & $\mathbf{4 0 . 7}$ & 1.5 \\
\hline & \multicolumn{3}{|c|}{ Compound Annual Growth Rate (CAGR) 2010-2017 } & 6.0 \\
\hline
\end{tabular}


Source: autors, based on the Republic Statistical Office data

In the period 2010-2017, High-technology industry exports grew at an average real annual rate of $6.0 \%$. The highest export growth was recorded in 2012 (annual growth of 37.6\%), 2010 (22.9\%) and 2015 (21.8\%), while in 2017 exports increased by $1.5 \%$, while in $2011(-21.9 \%)$ and $2013(-14.9)$ a decrease in exports was recorded. The value of exports in 2017 was 7.5 billion dinars and it was higher than in 2010, which indicated the strengthening of the international competitiveness of the domestic Hightechnology industry and its positioning in the global High-technology products market.

Graph 7. Export trends of High-technology industry in 2010-2017

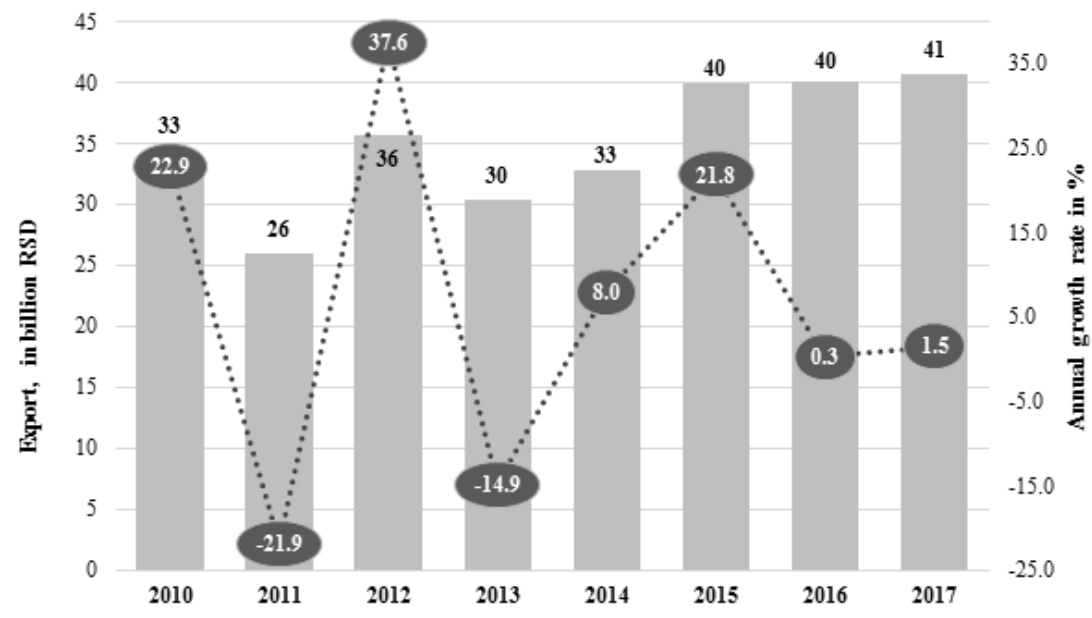

Source: autors, based on the Republic Statistical Office data

Exports of the domestic High-technology industry are dominated by basic pharmaceutical products and pharmaceutical preparations $(67.9 \%$ of exports of the High-technology industry in 2017), with exports of computer, electronic and optical products accounting for $32.1 \%$ of exports of the Hightechnology industry in 2017, which indicates the still low level of development of Manufacture of computer, electronic and optical products in Serbia.

\section{PROSPECTS FOR DEVELOPMENT OF HIGH-TECH INDUSTRY IN SERBIA}

The acceleration of the development of the High-technology industry in the world in the last few decades has positively influenced the development of these activities in Serbia, although the business conditions and the overall business and development situation in Serbia still do not allow full utilization of potential capacities in this field (Despotović at al, 2015). The solid 
developmental positions of the High-technology industry in the late 1980s have worn off considerably, and the development of new businesses has not yet reached the desirable level, so Serbia has significantly deteriorated its place on the global map of High-technology development. However, the overall trends in the domestic economy are positive, as they go towards the development of both new domestic companies of the High-technology industry, especially enterprises in the ITK area, as well as the arrival of foreign companies from the High-technology industry in the form of foreign direct investment, but also through cooperation with domestic companies in this field.

At the national level, particular attention has been paid to attracting foreign High-technology enterprises through state incentives to attract foreign direct investment in order to reduce the technological gap in the shortest possible time compared to the technologically advanced economies of the EU countries in particular. To this end, the Government of the Republic of Serbia undertakes a number of concrete activities to increase production in the Hightechnology industry, through the line Ministry of Economy and associated institutions (Development Agency of Serbia and the Development Fund), based on the Law on Investment and the Regulation on Attraction of Direct Investment. Incentives for attracting foreign and domestic investments have been allocated for the implementation of these activities at the state level, with the development of the High-technology industry being particularly emphasized.

In the period 2006-2018, on the basis of the budget of the Republic of Serbia, incentive funds for the implementation of five projects in the field of Hightechnology industry (one project in the field of Manufacture of basic pharmaceutical products and preparations and four projects in the field of Manufacture of computers, electronic and optical products) were approved. The value of these investment projects is around $€ 38$ million, so, at least 1.660 new employees will be employed, with incentive funding amounting to approximately $€ 10.5$ million. In three out of five subsidized projects are investors from Austria, Germany and the Netherlands, and in two projects are domestic investors. Individually, the highest value of the investment is the project "Construction and commissioning of an electronic goods factory in the city of Niš", implemented by Integrated Micro-Electronics doo Niš. The value of this project is $€ 26.7$ million and it will employ at least 1.250 workers. The state has subsidized this project with funds of 8.5 million euros.

Table 5. Subsidized direct investments in the High-technology industry in the period 2006-2018 
Nikola Savanović, Miro Sokić, Slađana Subotić

\begin{tabular}{|c|c|c|c|c|c|}
\hline $\begin{array}{l}\text { Name of } \\
\text { investor }\end{array}$ & $\begin{array}{l}\text { Origin of } \\
\text { investors }\end{array}$ & Industry & $\begin{array}{l}\text { Height of } \\
\text { investment } \\
\quad \text { (in } €)\end{array}$ & $\begin{array}{c}\text { New } \\
\text { workplaces }\end{array}$ & $\begin{array}{c}\text { Approved } \\
\text { incentives } \\
\quad(\text { in } €)\end{array}$ \\
\hline $\begin{array}{c}\text { AVE } \\
\text { Pharmaceutical } \\
\text { d.o.o. Beograd }\end{array}$ & Serbia & $\begin{array}{c}\text { Manufacture } \\
\text { of basic } \\
\text { pharmaceutical } \\
\text { products and } \\
\text { pharmaceutical } \\
\text { preparations }\end{array}$ & $2,200,000$ & 60 & 540,000 \\
\hline $\begin{array}{l}\text { Visaris d.o.o. } \\
\text { Zemun }\end{array}$ & Serbia & \multirow{4}{*}{$\begin{array}{l}\text { Manufacture } \\
\text { of computer, } \\
\text { electronic and } \\
\text { optical } \\
\text { products }\end{array}$} & 725,000 & 40 & 200,000 \\
\hline $\begin{array}{c}\text { TAGOR } \\
\text { Electronics doo } \\
\text { Nis }\end{array}$ & $\begin{array}{c}\text { Austria, } \\
\text { Serbia }\end{array}$ & & $1,250,000$ & 60 & 300,000 \\
\hline $\begin{array}{c}\text { Panasonic } \\
\text { Lighting } \\
\text { Devices Serbia } \\
\text { d.o.o. Svilajnac }\end{array}$ & Germany & & $7,000,000$ & 251 & $1,000,000$ \\
\hline $\begin{array}{c}\text { Integrated } \\
\text { Micro- } \\
\text { Electronics doo } \\
\text { Niš } \\
\end{array}$ & Netherlands & & $26,733,300$ & 1,250 & $8,516,270$ \\
\hline \multicolumn{3}{|c|}{ Total: } & $37,908,300$ & 1,661 & $10,556,270$ \\
\hline
\end{tabular}

Source: autors, based on the Ministry of Economy data

The realization of these and many other projects in the field of High-technology industry strives for the necessary conditions for the accelerated and sustainable development of the High-technology industry in Serbia and the overall development of the domestic economy and society as a whole.

\section{CONCLUSION}

Based on previous findings, in order to make the growth and development of the High-technology industry in Serbia be more dynamic and sustainable, the systematic measures of an active economic policy need to stimulate and significantly improve all key activities in the complex value chain in the High-technology industry field, starting with the educational system that needs to produce quality professionals who, with their knowledge and ability, will be able to meet the challenges of 21 st century technology, through significant and more meaningful investment in science and various research and development projects (Krstić at al., 2018), capital market development that will be able to follow the innovative, up-and-coming growth companies, providing more favorable financial conditions for financing the development of existing and potentially new domestic producers in this field. The state should create the possibility that the creative spirit of domestic companies will revive by stimulating innovation through its procurement (Krstić at al., 
2019 , p. 28). At the same time, it is necessary to stimulate the arrival of new foreign producers in the form of FDI, which will provide a bridging of the technological gap in relation to the latest technological solutions and placement of High-technology industry products in new markets. It is also necessary to encourage, direct and link local companies from the Hightechnology industry into clusters, strategic alliances, technology parks, which would increase their competitiveness, technological, business and overall development potential. The aforementioned, as well as other measures of active economic policy are necessary in order to accelerate the development of the domestic High-technology industry and to make it really the basis of Serbia's economic and overall social development in the coming decades.

\section{REFERENCES}

1. Cvetanović, S. and Novaković, I., 2019. Commercalization of Knowledge Into Innovation in Theory of Economic Growth and Development, Knowledge. Selected Scientific Papers, 33.1, pp.15-20.

2. Cvetanović, S., Ilić, V., Despotović, D., Nedić, V., 2015. Spremnost za razvoj ekonomije bazirane na znanju, inovativnost i konkurentnost zemalja Zapadnog Balkana. Industrija, 43(3), str. 27-53.

3. Despotović, D., Cvetanović, D., Nedić, V., 2015. Perspektive za razvoj ekonomije znanja, inovativnost i konkurentnost zemalja CEFTA. Facta universitatis - series: Economics and Organization, 12(3), str. 209-223.

4. European Commission, 2009. Science, technology and innovation in Europe, Publications Office of the European Union, Luxembourg

5. Eurostat, 2019a. Archive: High-tech statistics - economic data, [online] Available at: <https://ec.europa.eu/eurostat/statisticsexplained/index.php?title=Archive:High-tech_statistics__economic_data> [Accessed September 19, 2019].

6. Eurostat, 2019b. Glossary: High-tech, [online] Available at: $<$ https://ec.europa.eu/eurostat/statistics-

explained/index.php?title=Glossary:High-tech $>$ [Accessed September 19, 2019].

7. Eurostat, 2019c. High-tech statistics - economic data: tables and figures, [online] Available at: https://ec.europa.eu/eurostat/statisticsexplained/index.php?title=Archive:High-tech_statistics__economic_data\#Publication> [Accessed September 22, 2019].

8. Filipović, M., Nikolić, M., 2017. Razvojna politika Srbije u 2017. predlozi za promenu postojeće politike podsticaja, Ekonomska politika Srbije u 2017. godini, Zbornik radova, Ekonomski fakultet u Beogradu, str. $157-176$

9. Filipovic, M., Nikolic, M. and Despotovic, D., 2016. Innovative Small and Medium-Sized Enterprises in The Knowledge-Based Economy, Ekonomika preduzeća, 64(3-4), pp. 225-238. 
10. Filipović, M., Nikolić, M., Ilić, V., 2015. Razvoj privrede zasnovane na znanju kao factor povećanja konkurentnosti privrede Srbije. Ekonomske teme, 53(2), str. 191-214.

11. Krstić, B., Krstić, M. and Đekić, I. 2018. A science as the determinant of competitiveness of countries - benchmarking study. U Krstić, B. (ed.) Enchancing the Efficiency and Competitiveness of Enterprises and National Economies - problems, factors, determinants, strategies and solutions (1-25), University of Nis, Faculty of Economics.

12. Krstić, M. S., Krstić, B. and Antonović, R. 2019. The Importance of Science for Improving Competitiveness of National Economy. Facta Universitatis, Series: Economics and Organization, pp.013-030.

13. Ministry of Economy, 2019. [online] Available at: http://privreda.gov.rs/ministarstvo-na-dlanu/sektori/odeljenje-zainvesticije/> [Accessed September 29, 2019].

14. Nedić, V. M., Cvetanović, S. Despotović, D., 2014. IKT kao komponenta razvoja ekonomije znanja zemalja Zapadnog Balkana. Industrija, 42(4), str. 55-77.

15. Nikolić, M., Stošković, M., Cvetanović, D., 2017. Neki indikatori izgradnje društva znanja baziranog na ekonomiji znanja Republike Srbije i izabranih zemalja, Anali ekonomskog fakulteta u Subotici, 53(37), str. 027-042

16. Pokrajac, S., 2010. Preduzetništvo: izazovi $i$ putevi "kreativne destrukcije" privrede Srbije, Beograd: Mašinski fakultet.

17. Republic Statistical Office, 2019. Annual indicators on business activities of enterprises, [online] Available at: http://data.stat.gov.rs/Home/Result/190101?languageCode=sr-Cyrl> [Accessed September 14, 2019].

Received: 26 November, 2019

Accepted: 13 December, 2019

Rad je primljen: 26.11.2019.

Prihvaćen za objavljivanje: 13.12.2019. 